\title{
Symptomatic Childhood Uremic Pericardial Effusion: An
}

\section{Echocardiography Image}

Aamir Jalal Al-Mosawi

1Advisor in Pediatrics and Pediatric Psychiatry, Children Teaching Hospital of Baghdad Medical City

2Head, Iraq Headquarter of Copernicus Scientists International Panel Baghdad, Iraq

*Corresponding author: Aamir Jalal Al-Mosawi. Advisor in Pediatrics and Pediatric Psychiatry Children Teaching Hospital of Baghdad Medical City

Received Date: September 09, 2020; Accepted Date: September 18, 2020; Published Date: September $25,2020$.

Citation: Al-Mosawi A J. (2020) Symptomatic childhood uremic pericardial effusion: An echocardiography image. Journal of Cardiology Research and Reports, 2(2): Doi: 10.31579/2690-1897/010

Copyright: ( ) 2020. : Aamir Jalal Al-Mosawi. This is an open-access article distributed under the terms of the Creative Commons Attribution License, which permits unrestricted use, distribution, and reproduction in any medium, provided the original author and source are credited.

\begin{abstract}
Large childhood symptomatic pericardial effusion demanding pericardio-centesis and pericardial drainage is rare and symptomatic childhood uremic pericardial effusion is even rarer. The aim of this paper is to report the rare occurrence of childhood uremic symptomatic pericardial effusion. A seven year old boy with the most extreme form of end-stage renal disease (anuric with no renal function). The patient developed large childhood symptomatic pericardial effusion which was diagnosed by echocardiography.
\end{abstract}

Keywords: Uremia; symptomatic pericardial effusion; pericardiocentesis

\section{Introduction}

Large childhood symptomatic pericardial effusion demanding pericardiocentesis and pericardial drainage is rare, and symptomatic childhood uremic pericardial effusion is even rarer $[1,2]$.

De la Morena Pardo (1989) studied twelve children with symptomatic pericardial effusion and diagnosed four of them as having idiopathic pericardial effusions. Other causes of symptomatic pericardial effusions were chronic renal failure, viral infection, cardiac surgery, juvenile rheumatoid arthritis and chronic myelocytic leukemia [1].

Guven et al (2007) studied 10 (6 male, 4 female) children (mean age: 8.05 $+/-4.4$ yr) large symptomatic pericardial effusion needing pericardiocentesis and pericardial drainage. They found three patients had tuberculosis, one patient had uremic pericarditis; one patient had bacterial pericarditis; one patient had post-pericardiotomy syndrome; two patients had malignancy and two patients had no identifiable cause.

Guven et al suggested that tuberculosis is the most important cause of large symptomatic pericardial effusion particularly in the developing countries [2].

\section{Patients and methods}

A seven year old boy with the most extreme form of end-stage renal disease (anuric with no renal function). The patient developed large childhood symptomatic pericardial effusion which was diagnosed by echocardiography (Figure-1) demanding pericardiocentesis and pericardial drainage during treatment with intermittent peritoneal dialysis and conservative medical treatment (low protein diet and fluid restriction). He was treated with peritoneal dialysis sessions intermittently whenever became symptomatic with marked nausea, tachypnea (acidotic breathing), and generalized edema from fluid overload.

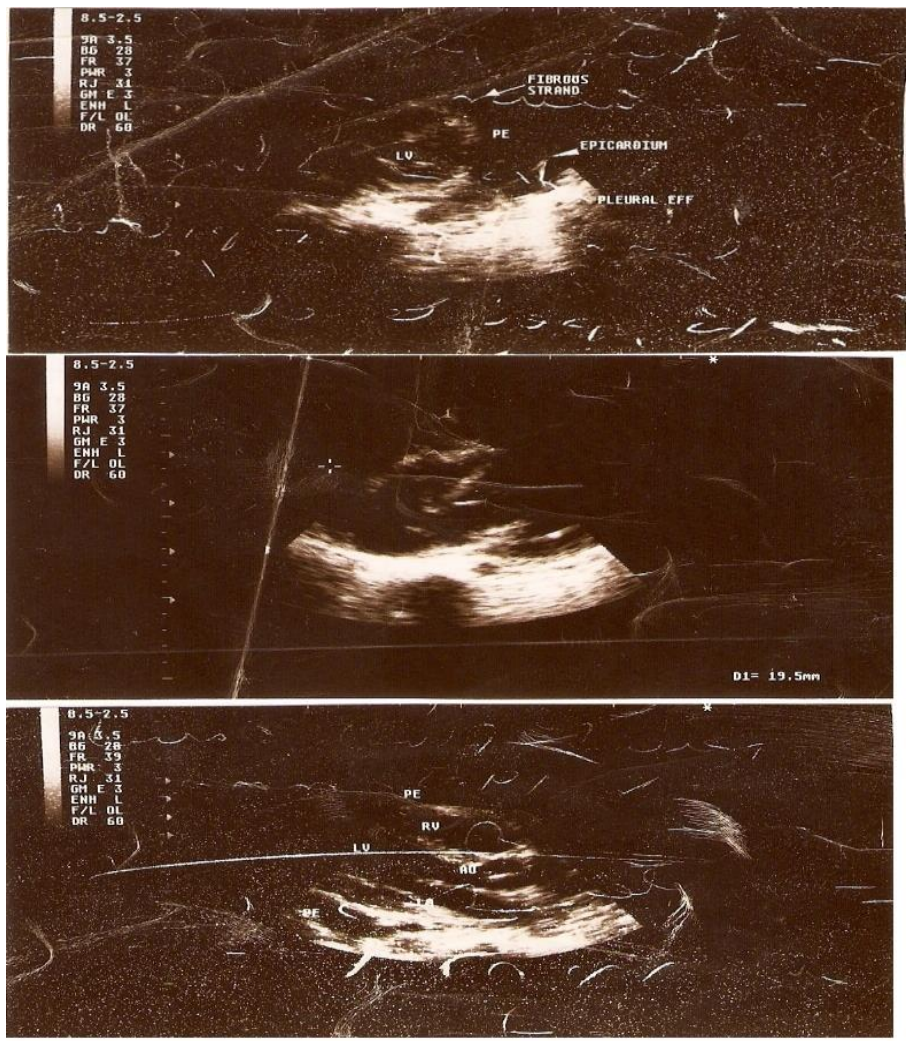

Figure-1: A seven year old boy with the most extreme form of end-stage renal disease (anuric with no renal function). The patient developed large childhood symptomatic pericardial effusion which was diagnosed by echocardiography 


\section{Discussion}

Uremic pericarditis without pericardial effusion was considered a common complication of renal failure during the 1950s ad 1960s. It generally the result of an aseptic inflammation associated with fibrin formation, and little or no fluid [3, 4, 5]. The occurrence of large symptomatic uremic pericardial effusion was rarely reported in adult's patients during the 1950s and 1960s [3, 6, 7, 8, 9, 10]. Fishberg (1954) reported the occurrence of considerable serous or hemorrhagic effusion [3].

Goodner and Brown (1956) reported the deaths of two young male's patients with chronic renal disease because of large symptomatic uremic pericardial effusion. Postmortem studies of the two patients revealed 800 and $850 \mathrm{ml}$ of blood-stained fluid were present in the pericardial cavities [6].

Lowry and Boyd (1960) studied 227 cases of uremic pericarditis, and found 58 patients with hydropericardium and 3 with massive hemopericardium [10].

Rappaport (1962) reported the occurrence of large symptomatic uremic pericardial effusion in a ten year old girl.

Large symptomatic uremic pericardial effusion is a very rare condition during childhood [11, 12, and 13].

\section{Conclusion}

This paper documented the rare occurrence of large symptomatic uremic pericardial effusion requiring drainage during childhood.

\section{References}

1. de la Morena Pardo ML, Chamorro Romero MI, Prados Bueno R, de Inocencio Arocena J, Maroto Alvaro E, García Fernández EJ. (1989). Derrames pericárdicos sintomáticos en la edad pediátrica [Symptomatic pericardial effusions in childhood]. An Esp Pediatr, 31(6):528-532. PMID: 2698067.
2. Guven H, Bakiler AR, Ulger Z, Iseri B, Kozan M, Dorak C. (2007). Evaluation of children with a large pericardial effusion and cardiac tamponade. Acta Cardiol. 62(2):129-133. PMID: 17536600 .

3. Fishberg AM. Hypertension and Nephritis, 5th ed. Bailliere, Tyndall and Cox, London, 1954.

4. De Wardener HE. The kidney, 2nd ed. Churchill, London, 1961.

5. Wood PH. Diseases of the heart and circulation, 2nd ed. Eyre and Spottiswoode, London, 1961.

6. Brown H, Goodner CJ. (1956). Report of two cases of cardiac tamponade in uremic pericarditis. J Am Med Assoc, 162(16):1459-1461.PMID:13376317.

7. Guild WR, Bray G, Merrill JP. (1957). Hemopericardium with cardiac tamponade in chronic uremia. $\mathrm{N}$ Engl $\mathrm{J}$ Med. 257(5):230-231. PMID: 13452081.

8. Hutt MP, Holme S JH. (1961). Pericardial effusion complicating acute tubular necrosis. Arch Intern Med. 108:226230. PMID: 13717083.

9. Merikas G, Samartzis M, Marketos S. (1962). Massive cardiac tamponade in uremic pericarditis with complete recovery. $\mathrm{N}$ Engl J Med. 266:1089-1091. PMID: 14472818.

10. Lowy AC, Boyd LJ. (1960). Some clinical aspects of uremic pericarditis. Exp Med Surg, 18:90-97.PMID: 13763870.

11. Rappaport HR. (1962). Uremic pericarditis and tamponade in a ten year old girl. J Mt Sinai Hosp N Y, 29:334-338. PMID: 14490380.

12. Al-Mosawi AJ. (2002). the etiology of chronic renal failure in 54 Iraqi children. Pediatr Nephrol. 17(6):463-4. PMID: 12162275 .

13. Al-Mosawi AJ . (2008). Chronic renal failure in Iraqi children: 14 year experience of a single center. Journal of Nephrology and Renal Transplantation (JNRT) 1(1): 32-40.

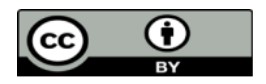

This work is licensed under Creative Commons Attribution 4.0 License

To Submit Your Article Click Here: Submit Article

DOI: $10.31579 / 2690-1897 / 010$
Ready to submit your research? Choose Auctores and benefit from:

$$
\begin{aligned}
& \text { fast, convenient online submission } \\
& \text { rigorous peer review by experienced research in your field } \\
& \text { rapid publication on acceptance } \\
& \text { * authors retain copyrights } \\
& \text { unique DOI for all articles } \\
& \text { immediate, unrestricted online access }
\end{aligned}
$$

At Auctores, research is always in progress.

Learn more www.auctoresonline.org/journals/cardiology-researchand-reports- 